restricting dietary protein on the progression of renal failure in patients with insulin-dependent diabetes mellitus. $N$ Engl $\tilde{J}$ Med 1991;324:78-84.

56 Lubowitz $\mathrm{H}$, Slatopolsky $\mathrm{F}$, Shankel $S$, Riesthach $\mathrm{RF}$, Bricker NS.

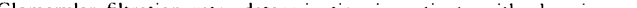
disease YAMA 1967;199:252-6.

$57 \mathrm{Klahr}$ S. The modification of diet in renal disease study. $N$ Engl f Med 1989;320:864-6.

58 Gretz N, Zeier M, Geberth S, Strauch M, Ritz E. Is gender a determinant for evolution of renal failure? A study in autosomal dominant polycystic kidney disease. Am F Kidney Dis 1989;14:178-83.
59 Cianciaruso B, Capuano A, D'Amaro E, Ferrera N, Nastasi A, Conte G, et al. Dietary compliance to a low protein and phosphate diet in patients with chronic renal failure. Kidney Int 1989;36 (suppl 27): S173-6.

60 Kopple JD), Berg R, Houser H, Steinman TI, Teschan P (MDRD Study Group). Nutritional status of patients with different levels of chronic renal insufficiency. Kidney Int 1989;36 (suppl 27): S184-94.

61 Maroni BJ, Steinman TI, Mitch WE. A method for estimating nitrogen intake of patients with chronic renal failure. Kidney Int 1985;27:58-65.

(Accepted 4 November 1991)

\title{
Mortality and occupational exposure to radiation: first analysis of the National Registry for Radiation Workers
}

\author{
G M Kendall, C R Muirhead, B H MacGibbon, J A O'Hagan, A J Conquest, A A Goodill, \\ B K Butland, T P Fell, D A Jackson, M A Webb, R G E Haylock, J M Thomas, T J Silk
}

Abstract
Objective-To study cause specific mortality of radiation workers with particular reference to associations between fatal neoplasms and level of exposure to radiation.

Design-Cohort study.

Setting-United Kingdom.

Subjects -95217 radiation workers at major sites of the nuclear industry.

Main outcome measure-Cause of death.

Results-Most standardised mortality ratios were below 100: 83 unlagged, 85 with a 10 year lag for all causes; 84 unlagged, 86 lagged for all cancers; and 80 for all known other causes, indicating a "healthy worker effect." The deficit of lung cancer (75 unlagged, 76 lagged) was significant at the $0 \cdot 1 \%$ level. Standardised mortality ratios were signifcantly raised (214 unlagged, 303 lagged) for thyroid cancer, but there was no evidence for any trend with external recorded radiation dose. Dose of external radiation and mortality from all cancers were weakly correlated $(p=0 \cdot 10)$, and multiple myeloma was more strongly correlated $(p=0.06)$; for leukaemia, excluding chronic lymphatic, the trend was significant $(p=0.03$; all tests one tailed). The central estimates of lifetime risk derived from these data were $10.0 \%$ per $\mathrm{Sv}(90 \%$ confidence interval $<0$ to $24 \%)$ for all cancers and $0.76 \%$ per $\mathrm{Sv}(0.07$ to $2.4 \%)$ for leukaemia (excluding chronic lymphatic leukaemia). These are, respectively, 2.5 times and 1.9 times the risk estimates recommended by the International Commission on Radiological Protection, but $\mathbf{9 0 \%}$ confidence intervals are large and the commission's risk factors fall well within the range. The positive trend with dose for all cancers, from which the risk estimate was derived, was not significant. The positive association between leukaemia (except chronic lymphatic leukaemia) was significant and robust in subsidiary analyses. This study showed no association between radiation exposure and prostatic cancer.

Conclusion - There is evidence for an association between radiation exposure and mortality from cancer, in particular leukaemia (excluding chronic lymphatic leukaemia) and multiple myeloma, although mortality from these diseases in the study population overall was below that in the general population. The central estimates of risk from this study lie above the most recent estimates of the International Commission on Radiological Protection for leukaemia (excluding chronic lymphatic leukaemia) and for all malignancies. However, the commission's risk estimates are well within the $90 \%$ confidence intervals from this study. Analysis of combined cohorts of radiation workers in the United
States indicated lower risk estimates than the commission recommends, and when the American data are combined with our analysis the overall risks are close to those estimated by the commission. This first analysis of the National Registry for Radiation Workers does not provide sufficient evidence to justify a revision in risk estimates for radiological protection purposes.

\section{Introduction}

Estimates of the risks of ionising radiation rest mainly on evidence from Japanese atomic bomb survivors and from people exposed for medical reasons. These groups provide information on risks from exposure to high doses at high dose rates. There is little direct evidence of the effects of lower doses and dose rates typical of occupational exposures. To provide such direct evidence the National Radiological Protection Board, after extensive consultation with the nuclear industry and other interested groups, set up the National Registry for Radiation Workers in 1976 as the national study of radiation workers, following individuals through different employments.

The first analysis of the registry covers over 95000 radiation workers whose collective dose from external radiation is about 3200 man Sv. The essentials of the study are described in this paper; more details can be found in a separate report.

\section{Methods}

Although the study population for the National Registry for Radiation Workers is broadly defined, practical considerations have limited the first analysis to certain groups. Radiation workers were divided into four categories: (a) those in radiation work when the registry was set up; $(b)$ those in employment at the inception of the study but no longer doing radiation work; (c) those who had left employment before the inception of the study; and $(d)$ those starting radiation work after the inception of the study.

It was recognised that it would be easier to ensure that data were complete and accurate for those still in radiation work, and at the request of the participating organisations those in categories $(a)$ and $(d)$ were generally the first to be enrolled. The first analysis of the registry includes the following groups of workers: from British Nuclear Fuels, category $(a)$ and $(d)$ workers from 1 January 1976, with category $(b)$ and $(c)$ for Sellafield and Chapelcross; from the Ministry of Defence Atomic Weapons Establishment, workers in all categories; from the Ministry of Defence, Defence Radiological Protection Service, workers in categories $(a)$ and $(d)$ from 1 January 1977; from Nuclear Electric,
Correspondence to:

Dr Kendall.

BMf 1992;304:220-5
BMJ VOLUME 304

25 JANUARY 1992 
workers in categories $(a)$ and $(d)$ from 1 January 1983 at 11 sites (see table II); and from the United Kingdom Atomic Energy Authority, workers in all categories.

Certain of the participants in the registry had been included in other epidemiological studies: those of the United Kingdom Atomic Energy Authority, covering participants in employment to the end of $1979^{4}$; British Nuclear Fuels Sellafield, covering those in employment to the end of $1975^{5}$; the Atomic Weapons Establishment, covering those in employment to the end of $1982^{6}$; and British Nuclear Fuels Chapelcross, covering those in employment to the end of $1983 .{ }^{?}$

The follow up date for most workers for this first analysis of the National Registry for Radiation Workers is 31 December 1988. A combined analysis of the first three groups already studied, based on a longer period of follow up, is to be published shortly. This extension of the data on these groups will be included in a subsequent analysis of the registry. In the present analysis workers in category (c) were not followed up beyond the dates for the studies already published.

Radiation workers are given the opportunity to refuse to participate in the registry. However, less than $1.5 \%$ chose to do so, and anonymised statistical data ${ }^{2}$ suggested that those who refused to participate were generally similar to participants.

Data collected from the employers consisted of

TABLE I-Study population by year of birth and sex

\begin{tabular}{lccc}
\hline Year of birth & $\begin{array}{c}\text { Men } \\
(\mathrm{n}=87522)\end{array}$ & $\begin{array}{c}\text { Women } \\
(\mathrm{n}=7695)\end{array}$ & $\begin{array}{c}\text { Total } \\
(\mathrm{n}=95217)\end{array}$ \\
\hline Before 1915 & 6141 & 262 & 6403 \\
$1915-$ & 3294 & 163 & 3457 \\
$1920-$ & 5978 & 383 & 6361 \\
$1925-$ & 6892 & 410 & 7302 \\
$1930-$ & 7378 & 597 & 7975 \\
$1935-$ & 7570 & 718 & 8288 \\
$1940-$ & 8236 & 736 & 8972 \\
$1945-$ & 10497 & 583 & 11080 \\
$1950-$ & 10120 & 739 & 10859 \\
$1955-$ & 11251 & 1401 & 12652 \\
$1960-$ & 7925 & 1210 & 9135 \\
$1965-$ & 2228 & 492 & 2720 \\
$1970-$ & 12 & 1 & 13 \\
Mean lifetime & & & \\
radiation dose & & 6.1 & \\
(mSv) & 36.0 & & 33.6 \\
\hline
\end{tabular}

individual identifiers, information on factors such as date of birth and sex that affect the expected pattern of mortality, and radiation dose histories. Table I gives the breakdown by date of birth and sex of participants in the registry. It shows that the study population was predominantly (92\%) male and still quite young; the median date of birth was 1944 .

Most of the 95217 participants had had only one period of radiation work, but about $5 \%$ had had two or more such employments. In these cases a unified dose and employment history was set up.

For this first analysis of the registry, sites were able to provide data on exposures to external radiation only. These data are far more detailed and precise than the information normally available for occupational studies. Nevertheless, personal records of radiation exposure were kept primarily to comply with legal or administrative dose limits. For this analysis corrections were applied for notional doses, threshold doses, and changes in calibration quantity. ${ }^{2}$ After these corrections the collective external dose was 3198 man Sv. Table II shows that $62 \%$ of the workers had a lifetime dose $<10 \mathrm{mSv}$ and that $9 \%$ had a lifetime dose $>100 \mathrm{mSv}$. Just under half of those with doses $>100 \mathrm{mSv}$ worked at Sellafield, although there were also large numbers with such doses working in the United Kingdom Atomic Energy Authority, the Defence Radiological Protection Service, and Nuclear Electric.

Follow up information was obtained primarily from the National Health Service central registers for England and Wales and for Scotland. Use was also made of the tracing facilities of the records branch of the Department of Social Security and various other organisations. ${ }^{2}$ Of the 95217 radiation workers, 69 could not be traced satisfactorily, 1850 were recorded as having emigrated, and 6660 were recorded as having died by the end of follow up.

Personal and dose information were checked against health physics records, apart from those for the cohorts that were the subject of published reports on the Atomic Weapons Establishment, Sellafield, and United Kingdom Atomic Energy Authority workforces. A low level of errors was found. One per cent sample checks of the follow up information were

TABLE II - Study population by lifetime radiation dose and site of first employment

\begin{tabular}{|c|c|c|c|c|c|c|c|c|c|c|c|c|}
\hline \multirow[b]{2}{*}{ Employer and site } & \multicolumn{7}{|c|}{ Dose range $(\mathrm{mSv})$} & \multirow{2}{*}{$\begin{array}{c}\text { No of } \\
\text { workers }\end{array}$} & \multirow{2}{*}{\multicolumn{2}{|c|}{$\begin{array}{c}\text { Collective } \\
\text { dose } \\
(\operatorname{man} S v)^{\star}\end{array}$}} & \multirow{2}{*}{\multicolumn{2}{|c|}{$\begin{array}{c}\text { Mean } \\
\text { dose } \\
(\mathrm{mSv})\end{array}$}} \\
\hline & $<1$ & 10 & 0 - & $50-$ & & & 100 & & & & & \\
\hline British Nuclear Fuels & \multicolumn{2}{|c|}{10223} & 7464 & & 3083 & & 4847 & 25617 & & 1805 & & $70 \cdot 4$ \\
\hline Capenhurst & 1393 & 114 & & 6 & & 4 & +0 & 1517 & 5 & & $3 \cdot 6$ & \\
\hline Chapelcross & 462 & 567 & & 351 & & 451 & & 1831 & 141 & & $76 \cdot 7$ & \\
\hline Risley & 665 & 56 & & 6 & & 4 & & 731 & 3 & & $4 \cdot 5$ & \\
\hline Sellafield & 5348 & 4730 & & 2222 & & 4093 & & 16393 & 1519 & & $92 \cdot 7$ & \\
\hline Springfields & 2355 & 1997 & & 498 & & 295 & & 5145 & 136 & & \multicolumn{2}{|l|}{$26 \cdot 5$} \\
\hline Ministry of Defence Atomic Weapons Establishment & \multicolumn{2}{|c|}{8599} & 1249 & & 239 & & 154 & 10241 & & 85 & & $8 \cdot 3$ \\
\hline Defence Radiological Protection Service & \multicolumn{2}{|c|}{20717} & 4635 & & 1018 & & 876 & 27246 & & 381 & & $14 \cdot 0$ \\
\hline Navy & 7376 & 1623 & & 133 & & 37 & & 9169 & 61 & & $6 \cdot 6$ & \\
\hline Army & 2535 & 315 & & 42 & & 49 & & 2941 & 25 & & $8 \cdot 6$ & \\
\hline RAF & 4275 & 491 & & 6 & & 1 & & 4773 & 17 & & $3 \cdot 7$ & \\
\hline Civilian & 6531 & 2206 & & 837 & & 789 & & 10363 & 277 & \multirow{2}{*}{\multicolumn{2}{|c|}{$198^{26 \cdot 7}$}} & \\
\hline Nuclear Electric & \multicolumn{2}{|c|}{4490} & 2533 & & \multicolumn{2}{|l|}{696} & 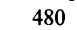 & 8199 & & & & $24 \cdot 1$ \\
\hline Berkeley & 127 & 221 & & 111 & & 182 & & 641 & 44 & & $68 \cdot 7$ & \\
\hline Bradwell & 190 & 245 & & 128 & & 85 & & 648 & 28 & & $43 \cdot 3$ & \\
\hline Dungeness $\mathrm{A}$ & 362 & 258 & & 47 & & 2 & & 669 & 12 & & $17 \cdot 4$ & \\
\hline Dungeness $B$ & 541 & 126 & & 17 & & 0 & 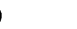 & 684 & 5 & & $8 \cdot 0$ & \\
\hline Hartlepool & 1286 & 62 & & 5 & & 4 & 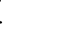 & 1357 & 5 & & 3.5 & \\
\hline Heysham & 496 & 17 & & 2 & & 0 & & 515 & 1 & & 1.5 & \\
\hline Hinkley Point & 498 & 749 & & 214 & & 85 & & 1546 & 49 & & $31 \cdot 4$ & \\
\hline Oldbury & 332 & 329 & & 49 & & 2 & & 712 & 12 & & $17 \cdot 2$ & \\
\hline Trawsfynydd & 179 & 260 & & 112 & & 120 & & 671 & 35 & & $51 \cdot 8$ & \\
\hline Wylfa & 466 & 262 & & 11 & & 0 & & 739 & 7 & & $10 \cdot 0$ & \\
\hline Not in power stations & 13 & 4 & & 0 & & 0 & 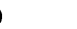 & 17 & 0 & & $5 \cdot 6$ & \\
\hline United Kingdom Atomic Energy Authority & \multicolumn{2}{|c|}{14916} & 5455 & & 1631 & & 1912 & 23914 & & 730 & & $30 \cdot 5$ \\
\hline Dounreay & 3086 & 1853 & & 584 & & 710 & & 6233 & 254 & & $40 \cdot 7$ & \\
\hline Harwell & 9300 & 2701 & & 716 & & 730 & & 13447 & 310 & & $23 \cdot 1$ & \\
\hline Risley & 598 & 146 & & 20 & & 8 & & 772 & 7 & & $9 \cdot 6$ & \\
\hline Winfrith & 1932 & 755 & & 311 & & 464 & & 3462 & 159 & & $45 \cdot 9$ & \\
\hline
\end{tabular}

^Figures for individual sites, subtotals by employer, and total dose have been accumulated separately to greater precision than shown here, then rounded to the nearest manSv. 


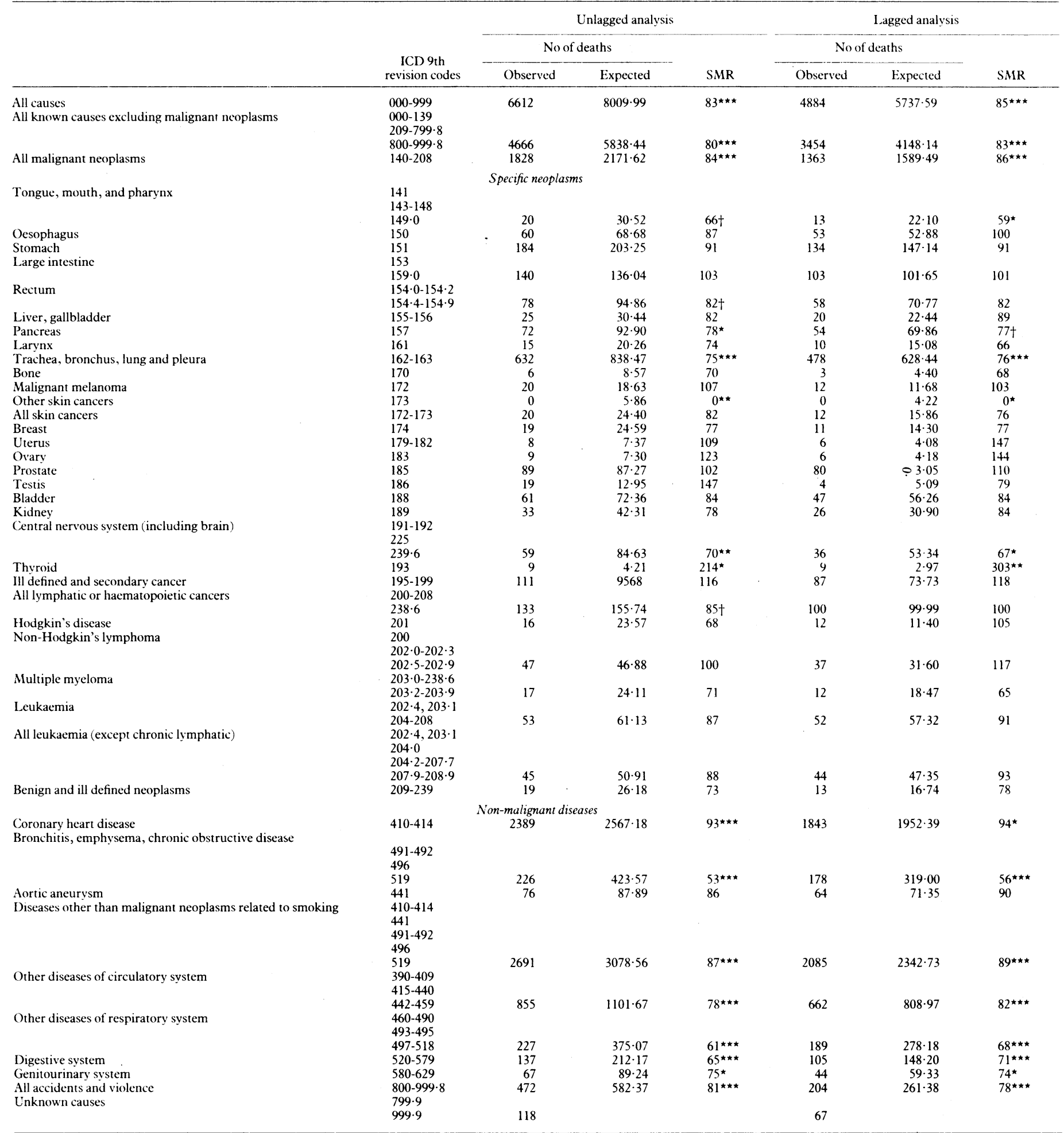

$+0 \cdot 05<p<0 \cdot 1,{ }^{\star} p<0 \cdot 05,{ }^{\star \star} p<0 \cdot 01,{ }^{\star \star \star} p<0 \cdot 001$.

performed at the NHS central register and the Department of Social Security, and the mortality information held at the central register for those on the National Register for Radiation Workers was also checked. There was a low level of incompleteness in the follow up data, which was corrected to a large extent by intercomparisons of data held by other research groups, the NHS central register, and the Department of Social Security.

Two types of analysis are presented. The first, external, analysis is of standardised mortality ratios in which the death rates in registry participants are compared with those in the general population of England and Wales. The second, internal, analysis is a test for trend with dose in which steps are taken to allow for factors that might obscure a dose-effect relation-for example, social class.

In the external analysis the follow up data were stratified by age in five year groups (up to 85 years), calendar years from 1955 to 1988 , and sex, and comparisons were made with the corresponding mortality in England and Wales, as supplied by the Office of Population Censuses and Surveys, by calculating standardised mortality ratios with the program PERSON-YEARS. ${ }^{8}$ Where necessary, bridge codes were used to convert death rates to disease groupings based on the ninth revision of the International Classification of Diseases. Significance tests for the standardised mortality ratios were two tailed in view of a likely "healthy worker effect." Mortality rates specific to 
social classes I and III ${ }^{10-12}$ were used in an analysis of non-industrial and industrial workers respectively (this is a division, widely used in the nuclear industry, that separates social classes I, II, III non-manual from III manual, IV, V; for the armed forces the division chosen was officers $v$ other ranks). To allow for the latency of any radiation effect, as well as the healthy worker effect, "lagged" analyses were also performed, in which deaths in the first two years after the start of radiation work were excluded for leukaemia and the first 10 years were excluded for other causes. The external analysis was based on the underlying cause of death recorded on the death certificate to facilitate comparison with national mortality rates.

In the internal analysis tests for trend in mortality with recorded dose from external radiation were made by using the program ARFAR, ${ }^{1314}$ with stratification by age (in five year groups up to 85 years), calendar period (1955-, 1960-, up to 1980-, 1985-8), sex, industrial classification, and first employer (British Nuclear Fuels Sellafield, Chapelcross, other; Nuclear Electric; Atomic Weapons Establishment; Defence Radiological Protection Service; United Kingdom Atomic Energy Authority Dounreay, Winfrith, Risley or Culcheth, Harwell or Culham or London). To allow for latency, doses were lagged by 10 years (except for leukaemia, for which a lag of two years was used); in addition, the same number of years after the start of radiation work were excluded. A score statistic was used to test for any trend in risk with dose, ${ }^{1315}$ and maximum likelihood estimates and $90 \%$ confidence intervals for excess relative risk per unit dose were calculated. ${ }^{15}$ Preference was given to one tailed tests in view of the prior hypothesis that cancer rates would increase with increasing dose and because the internal analysis took additional account of confounding factors. The cause of death in this analysis was taken to be leukaemia, non-Hodgkin's lymphoma, or multiple myeloma if these were coded anywhere on the death certificate; otherwise neoplasms were selected in preference to other diseases.

\section{Results}

Table III shows standardised mortality ratios by cause of death. For the whole period of follow up (analysis without lagging), the standardised mortality ratio for all causes was 83 ; that for all malignant neoplasms was 84 , and the ratio for all known other causes was 80 . All of these ratios were significantly below $100(p<0 \cdot 001)$. For most specific types of cancer the ratios were in the range $60-100$. The deficit for lung cancer (75) was significant at the $0 \cdot 1 \%$ level. For all leukaemias the ratio was 87 ; excluding chronic lymphatic leukaemia changed this value to 88 . The standardised mortality ratio for thyroid cancer was significantly greater than $100(214, \mathrm{p}<0.05)$, based on nine deaths.

For the lagged analysis excluding the first two years (leukaemia) or first 10 years (other cancers) after the start of radiation work, the results were broadly similar

TABLE IV-Standardised mortality ratios (SMRs) for all causes and all cancers tabulated by year since first exposure

\begin{tabular}{lcccccc}
\hline $\begin{array}{l}\text { No of years } \\
\text { since first } \\
\text { exposure }\end{array}$ & \multicolumn{3}{c}{ All causes of death } & \multicolumn{3}{c}{ All cancers } \\
\cline { 2 - 3 } \cline { 6 - 7 } & No observed & No expected & SMR & No observed & No expected & SMR \\
\hline $0-1$ & 212 & $314 \cdot 9$ & $87^{\star \star \star}$ & 51 & $76 \cdot 6$ & $67^{\star \star}$ \\
$2-4$ & 450 & $626 \cdot 8$ & $72^{\star \star \star}$ & 112 & $159 \cdot 4$ & $70^{\star \star \star}$ \\
$5-9$ & 1066 & $1330 \cdot 7$ & $80^{\star \star \star}$ & 308 & $355 \cdot 7$ & $87^{\star}$ \\
$10-14$ & 1178 & $1472 \cdot 6$ & $80^{\star \star \star}$ & 330 & $397 \cdot 5$ & $83^{\star \star \star}$ \\
$15-19$ & 1332 & $1523 \cdot 9$ & $87^{\star \star \star}$ & 346 & $414 \cdot 8$ & $83^{\star \star \star}$ \\
$20-29$ & 1941 & $2248 \cdot 2$ & $86^{\star \star \star}$ & 556 & $641 \cdot 1$ & $87^{\star \star \star}$ \\
$\geqslant 30$ & 433 & $492 \cdot 9$ & $88^{\star \star}$ & 144 & $152 \cdot 8$ & 94 \\
\hline
\end{tabular}

$\chi$ for trend

$20 \cdot 6^{\star \star \star}$

$4 \cdot 88^{\star}$
TABI.E $\mathrm{v}-$ Standardised mortality ratios (SMRs) for all cause tabulated by industrial category and adjusted or not adjusted for social clas

\begin{tabular}{|c|c|c|c|c|c|}
\hline \multirow[b]{3}{*}{$\begin{array}{l}\text { Industrial } \\
\text { category }\end{array}$} & \multicolumn{3}{|c|}{ No of deaths } & \multirow{2}{*}{\multicolumn{2}{|c|}{ SMR }} \\
\hline & & $\operatorname{Exp}$ & ected & & \\
\hline & Observed & $\begin{array}{c}\text { Not } \\
\text { adjusted }\end{array}$ & Adjusted & $\begin{array}{c}\text { Not } \\
\text { adjusted }\end{array}$ & Adjusted \\
\hline Industrial & 4750 & $5106 \cdot 07$ & $5310 \cdot 00$ & $93^{\star \star \star}$ & $89^{\star \star \star}$ \\
\hline Non industrial & 1724 & 2753.63 & 2014.98 & $63^{\star \star \star}$ & $86^{\star \star \star}$ \\
\hline Unclassified & 138 & $150 \cdot 29$ & & 92 & \\
\hline
\end{tabular}

TABLE VI-Standardised mortality ratios (SMRS) for all causes tabulated by sex

\begin{tabular}{lcrc}
\hline & \multicolumn{2}{c}{ No of deaths } & \\
\cline { 2 - 3 } & Observed & Expected & SMR \\
\hline Men & 6434 & $7775 \cdot 30$ & $83^{\star \star \star}$ \\
Women & 178 & $234 \cdot 68$ & $76^{\star \star \star}$ \\
\hline$\star \star \star \mathrm{p}<0 \cdot 001$. & & &
\end{tabular}

to those of the unlagged analysis (table III). The standardised mortality ratio for all malignant neoplasms was $86(\mathrm{p}<0.001)$ and that for leukaemia excluding chronic lymphatic leukaemia was 93 . As in the unlagged analysis, the ratio for thyroid cancer was significantly higher in the lagged analysis (303, $\mathrm{p}<0.01$ ).

Table IV shows that the standardised mortality ratio for all causes was low in the first few years after starting radiation work and then rose towards a plateau after 15-20 years. For all malignant neoplasms the ratio was 70 or just below 70 in the first five years but was fairly constant thereafter.

Based on mortality in the population of England and Wales, the all cause standardised mortality ratio among industrial workers was significantly greater than that for non-industrial workers $\left(93 v 63 ; \chi^{2}=201, p<0.001\right.$ ) (table $\mathrm{V}$ ). The ratios based on death rates specific to social class were, however, similar for industrial and non-industrial workers. These calculations were approximate because of the choice of reference population, but they served to indicate that the difference in standardised mortality ratios between industrial and non-industrial groups is a reflection of national differences rather than a special feature of this population. Standardised mortality ratios for men and women did not differ significantly $\left(83 v 76, \chi^{2}=1 \cdot 3, \mathrm{p}>0 \cdot 1\right)$ (table VI).

Table VII summarises the internal analysis. For all malignant neoplasms the trend with dose was positive, but it did not reach significance $(p=0 \cdot 1)$. The estimate of the excess relative risk per unit dose was 0.47 / Sv $(90 \%$ confidence interval $-0 \cdot 12$ to $1 \cdot 20)$. Out of 25 distinct specific cancer types, the estimate of trend was positive in 12 and negative in 13 . For all leukaemias the trend with dose was positive and reached significance when chronic lymphatic leukaemia was excluded $(p=0.03$, one tailed test), in which case the estimated excess relative risk was $4 \cdot 3 / \mathrm{Sv}(0 \cdot 40$ to $13 \cdot 6)$. The increasing trend for multiple myeloma was almost significant $(p=0.06$; excess relative risk $=6.9 / \mathrm{Sv}$ $(-0.03$ to 46$))$. One other disease grouping, ill defined and secondary tumours, had a significant $(p<0.05)$ increasing trend with dose.

Several subsidiary analyses were performed. These investigated the effects of, for example, removing corrections made to the dose histories, altering the entry date for certain subgroups, excluding workers monitored for internal emitters, or excluding contributory causes of death from the internal analysis.' These subsidiary analyses did not suggest that the results of the main analysis were in any way atypical and, although they should not be over interpreted, the 
association between death due to leukaemia and radiation was usually stronger than in the main analysis; for all cancers the results were variable.

\section{Discussion}

This analysis of the National Registry for Radiation Workers is the first in a series. For practical reasons it does not include all cohorts of radiation workers for whom dose records are held in the registry, all the most recent data from three major cohorts, nor estimates of doses from internal emitters. Nevertheless, important results have been obtained from both external and internal analyses in the present study. There is strong evidence of a healthy worker effect. Mortality is lower in radiation workers than in the general population of England and Wales-overall and for most specific causes, including cancers. There are fewer deaths from lung cancer and other cancers related to smoking and from other diseases related to smoking. Four cancer groups had significantly low standardised mortality ratios, including the grouping of cancers of trachea, bronchus, lung and pleura.

For only one cancer was the standardised mortality ratio significantly raised-thyroid cancer. As about 30 specific cancer groupings were considered it is possible that one or two positive (and negative) associations would arise by chance. This may well be the case with thyroid cancer as there was no detectable trend with external recorded dose and no evidence of common occupational exposure at any particular site; also, none of the four thyroid neoplasms for which the results of histopathology were available was of the follicular type associated with radiation.

Greatest prior interest lay in leukaemia and myelomatosis, which were associated with the highest relative risks in the data on Japanese survivors ${ }^{16}$ and have been shown to have a high incidence in other studies of groups exposed to high radiation doses. ${ }^{17}$ Although the standardised mortality ratios for these disease groupings were below 100 , there was some evidence for an increase in mortality with radiation dose, and the association was significant for leukaemia (except chronic lymphatic leukaemia). There was no evidence for an association between prostatic cancer and radiation, in contrast to suggestions from other studies, ${ }^{46}$ despite the fact that the National Registry for Radiation Workers includes the data on which the other studies were based.

One of the objectives of studies of radiation workers is to obtain direct estimates of risks from exposures to low doses of radiation at low dose rates, for comparison with the risk factors derived by the International Commission on Radiological Protection mainly from high dose and high dose rate exposures of the Japanese atomic bomb survivors, with application of a dose and dose rate effectiveness factor of $2 .{ }^{18}$ With excess relative risks derived from internal analysis of the registry the central estimate of the total risk of radiation induced cancer for a British worker population is $10.0 \% / \mathrm{Sv}$, and that for leukaemia (excluding chronic lymphatic leukaemia) is $0 \cdot 76 \% / \mathrm{Sv}$. These are, respectively, 2.5 times and 1.9 times the current values recommended by the commission for a notional (world) worker population (4\%/Sv for all malignancies and $0 \cdot 4 \% / \mathrm{Sv}$ for leukaemias). Several points must be taken into account in interpreting these observations. Firstly, the greater dose range and longer follow up of the Japanese atomic bomb survivors give that study greater statistical power than the National Registry for Radiation Workers. The $\mathbf{9 0 \%}$ confidence intervals from the registry are wider than those of the comparable risk estimates from the International Commission on Radiological Protection based on the Japanese data (table VIII). Furthermore, the commission's risk estimates fall well within the $90 \%$ confidence bounds from the registry. Secondly, in a combined analysis of data on about 36000 radiation workers with a collective dose of 1140 man Sv in the United States, the central estimate of the trend in risk with dose was negative both for:all malignant neoplasms and for leukaemia (excluding chronic lymphatic leukaemia) (table VIII). ${ }^{19}$ For all malignant neoplasms, the upper limit of the $90 \%$ confidence interval in the American study was close to the central estimate from the National Registry for Radiation Workers and similar to the central estimate from the Japanese atomic bomb survivors, ${ }^{16}$ corresponding to a lifetime risk of about $8 \cdot 2 \% / \mathrm{Sv}$. For leukaemia, the upper limit of the $90 \%$ confidence interval in the American study was less than the central

TABLE VII - Test for trend in mortality with dose by broad cause, specific neoplasms, and non-malignant disease

\begin{tabular}{|c|c|c|c|c|c|c|c|c|c|c|c|c|c|c|c|c|c|c|c|c|}
\hline & \multicolumn{14}{|c|}{ Dose (mSv) } & \multirow{3}{*}{$\begin{array}{c}\text { Total } \\
\text { deaths in } \\
\text { informative } \\
\text { strata }\end{array}$} & \multirow{3}{*}{$\begin{array}{c}\text { Score } \\
\text { statistic }\end{array}$} & & & \multirow{3}{*}{$\begin{array}{c}\text { Excess } \\
\text { relative } \\
\text { risk } \\
\text { (per Sv) }\end{array}$} & \multirow{3}{*}{$\begin{array}{l}90 \% \text { Confidence } \\
\text { interval }\end{array}$} \\
\hline & \multicolumn{2}{|c|}{$<10$} & \multicolumn{2}{|c|}{10.} & \multicolumn{2}{|c|}{$20-$} & \multicolumn{2}{|c|}{ 50- } & \multicolumn{2}{|c|}{$100-$} & \multicolumn{2}{|c|}{$200-$} & \multicolumn{2}{|c|}{$\geqslant 400$} & & & \multicolumn{2}{|c|}{$\mathrm{p}$ Values } & & \\
\hline & Observed & Expected & Observed & Expected & Observed & Expected & Observed & Expected & Observed & Expected & Observed & Expected & Observed & Expected & & & 1 Tailed & 2 Tailed & & \\
\hline & & & & & & & & & \multicolumn{2}{|c|}{ Broad cause } & & & & & & & & & & \\
\hline $\begin{array}{l}\text { All causes } \\
\text { All malignant neoplasms }\end{array}$ & $\begin{array}{r}2030 \\
584\end{array}$ & $\begin{array}{r}2090.09 \\
627 \cdot 68\end{array}$ & $\begin{array}{l}532 \\
161\end{array}$ & $\begin{array}{l}502 \cdot 22 \\
149 \cdot 80\end{array}$ & $\begin{array}{l}750 \\
208\end{array}$ & $\begin{array}{l}755 \cdot 96 \\
221 \cdot 26\end{array}$ & $\begin{array}{l}573 \\
194\end{array}$ & $\begin{array}{l}557.15 \\
163.37\end{array}$ & $\begin{array}{l}443 \\
129\end{array}$ & $\begin{array}{l}442.73 \\
129.05\end{array}$ & $\begin{array}{l}343 \\
113\end{array}$ & $\begin{array}{r}310.76 \\
92.05\end{array}$ & $\begin{array}{r}153 \\
46\end{array}$ & $\begin{array}{r}165 \cdot 08 \\
51.79\end{array}$ & $\begin{array}{l}4824 \\
1435\end{array}$ & $\begin{array}{l}0.59 \\
1.28\end{array}$ & $\begin{array}{l}0.28 \\
0 \cdot 10\end{array}$ & $\begin{array}{l}0.56 \\
0.20\end{array}$ & $\begin{array}{l}0.101 \\
0.467\end{array}$ & $\begin{array}{l}-0.171 \text { to } 0.407 \\
-0.118 \text { to } 1.198\end{array}$ \\
\hline $\begin{array}{l}\text { All known causes (excluding } \\
\text { malignant neoplasms) }\end{array}$ & $1+13$ & 1433.89 & 358 & 344.08 & 531 & $522 \cdot 91$ & 377 & $385 \cdot 80$ & 309 & $307 \cdot 72$ & 228 & $215-37$ & 106 & $112 \cdot 23$ & 3322 & 0.03 & 0.49 & 0.98 & 0.006 & -0.297 to 0.355 \\
\hline $\begin{array}{l}\text { All known non-viotent causes } \\
\text { (excluding malignant neoplasms) }\end{array}$ & 1315 & $1340 \cdot 68$ & 344 & 319.98 & 491 & $489 \cdot 74$ & 354 & $364 \cdot 11$. & 293 & $291 \cdot 38$ & 220 & $205 \cdot 23$ & 102 & 107.88 & 3119 & 0.15 & 0.44 & 0.88 & 0.031 & -0.282 to 0.394 \\
\hline Accidents and violence & 98 & $93 \cdot 20$ & 14 & 24.09 & 40 & $33 \cdot 17$ & 23 & 21.69 & 16 & 16.34 & 8 & $10 \cdot 15$ & 4 & 4.35 & 203 & -0.56 & 0.71 & 0.57 & -0.462 & -1.294 to 1.223 \\
\hline & & & & & & & & & \multicolumn{2}{|c|}{ Specific neoplasms } & & & & & & & & & & \\
\hline Mouth, tongue, pharynx & 7 & $6 \cdot 22$ & 3 & 1.34 & 2 & 1.89 & 0 & $1 \cdot 41$ & & & 2 & $1 \cdot 13$ & 0 & 0.66 & 14 & -0.92 & 0.81 & & $<-1.958$ & $<-1.958$ to 2.475 \\
\hline Oesophagus & 22 & $19 \cdot 35$ & 4 & 5.88 & 12 & 8.73 & 5 & $7 \cdot 32$ & 4 & $6 \cdot 16$ & 6 & 4.38 & 1 & $2 \cdot 18$ & 54 & -0.76 & 0.77 & 0.47 & -0.942 & $\begin{array}{l}-1.778 \text { to } 1.130 \\
-1030\end{array}$ \\
\hline Stomach & 57 & $60 \cdot 4$ & 18 & 15.08 & 19 & $21 \cdot 82$ & 24 & $16 \cdot 62$ & 8 & 12.63 & 9 & 7.91 & 4 & 4.51 & 139 & -0.13 & 0.55 & 0.90 & $-0 \cdot 126$ & -1.201 to 2.133 \\
\hline Large intestine & 49 & 47.33 & 12 & $12 \cdot 40$ & 13 & 17.92 & 13 & $13 \cdot 42$ & 17 & 10.08 & 5 & 7.41 & 4 & 4.44 & 113 & -0.11 & 0.52 & 0.96 & -0.121 & -1.252 to 2.590 \\
\hline Rectum & 23 & $26 \cdot 40$ & 7 & 5.95 & 12 & 9.25 & 6 & 7.62 & 7 & 6.86 & 5 & 5.91 & 5 & 3.01 & 65 & 0.96 & 0.17 & 0.34 & 1.278 & -0.567 to 5.849 \\
\hline Liver, gallbladder & 12 & $11 \cdot 89$ & 3 & $2 \cdot 07$ & 3 & 2.72 & 0 & 1.68 & 1 & 1.09 & 1 & 0.44 & 0 & $0 \cdot 10$ & 20 & -0.05 & 0.45 & 0.89 & $-0 \cdot 196$ & $<-1.958$ to 12.83 \\
\hline Pancreas & 25 & $23 \cdot 49$ & 8 & $6 \cdot 17$ & 4 & $8 \cdot 60$ & 8 & 6.07 & 4 & 4.76 & 4 & 3.65 & 2 & $2 \cdot 26$ & 55 & -0.18 & 0.55 & 0.91 & -0.249 & -1.467 to 3.241 \\
\hline $\begin{array}{l}\text { Larynx } \\
\text { Trachea, bronchus, lung, pleura }\end{array}$ & 4 & $5 \cdot 17$ & 2 & $1 \cdot 16$ & 3 & 1.85 & 1 & 1.32 & 1 & 0.85 & 0 & 0.31 & 0 & 0.33 & 11 & -0.81 & 0.76 & 0.48 & $<-1.958$ & $<-1.958$ to 36.48 \\
\hline Trachea, bronchus, lung, pleura & 200 & $213 \cdot 43$ & 44 & $49 \cdot 74$ & 71 & $75 \cdot 26$ & 76 & 55.53 & 43 & 44.50 & 45 & $33 \cdot 26$ & 12 & $19 \cdot 28$ & 491 & 0.18 & 0.43 & 0.85 & 0.124 & -0.798 to 1.520 \\
\hline Bone & 2 & 1.64 & 0 & 0.23 & 1 & 0.30 & 0 & 0.19 & 0 & 0.17 & 0 & 0.27 & 0 & 0.20 & 3 & -1.03 & 0.89 & 0.19 & $<-1.958$ & $<-1.958$ to 4.325 \\
\hline All skin & 3 & +.18 & 1 & $1+42$ & 4 & 2.66 & 3 & $2 \cdot 16$ & 1 & $1 \cdot 40$ & 0 & & 1 & 0.32 & 13 & 0.52 & 0.29 & 0.57 & 1.500 & -1.200 to 47.82 \\
\hline Breast & 4 & 5.49 & 3 & 0.77 & 0 & $1 \cdot 12$ & 1 & $0 \cdot 38$ & 0 & $0 \cdot 17$ & 0 & 0.0 & 0 & 0.00 & 8 & -0.03 & 0.40 & 0.79 & -0.926 & $<-1.958$ to 155.7 \\
\hline Uterus & 3 & 3.35 & 0 & 0.15 & 1 & 0.39 & 0 & 0.11 & 0 & 0.01 & 0 & 0.00 & 0 & 0.00 & 4 & 0.29 & 75 & 0.45 & $25 \cdot 30$ & $<-1.958$ to 477.3 \\
\hline Ovary & 2 & $3 \cdot 41$ & & 0.32 & 2 & 0.15 & 0 & 0.09 & 0 & 0.02 & 0 & & 0 & 0.00 & 4 & $1 \cdot 23$ & & & $207 \cdot 1$ & $<-1.958$ to 608.2 \\
\hline Prosstatc & 38 & $46 \cdot 33$ & 12 & $8: 46$ & 12 & $13: 56$ & 12 & $9 \cdot 49$ & 12 & $7 \cdot 60$ & 6 & 4.85 & 2 & $3 \cdot 20$ & 94 & 0.55 & $0 \cdot 28$ & 0.55 & 1.518 & -1.409 ro 10.68 \\
\hline Testis & 1 & 2.15 & 2 & 0.64 & 0 & 1.04 & 2 & 0.76 & 1 & 0.73 & 0 & 0.51 & 0 & 0.17 & 6 & -0.49 & 0.63 & 0.72 & $<-1.958$ & $<-1.958$ to 83.53 \\
\hline Bladder & 20 & $24 \cdot 19$ & 5 & 5.76 & 11 & 7.34 & 4 & 5.56 & 5 & 4.76 & 5 & & 3 & 1.74 & 53 & 1.56 & & 0.14 & 3.575 & -0.114 เ 13.92 \\
\hline $\begin{array}{l}\text { Kidney } \\
\text { Central neryous system }\end{array}$ & 13 & 13.87 & 2 & 2.73 & 5 & 3.99 & 4 & 2.58 & 2 & $2 \cdot 25$ & 1 & $1 \cdot 21$ & 0 & 0.36 & 27 & -0.42 & 0.63 & 0.74 & -1.797 & $<-1.958$ to 11.25 \\
\hline $\begin{array}{l}\text { Central nervous system } \\
\text { Thyroid }\end{array}$ & $\begin{array}{l}10 \\
4\end{array}$ & $\begin{array}{l}12 \cdot 30 \\
3.31\end{array}$ & 1 & $\begin{array}{l}4.03 \\
0.68\end{array}$ & ${ }_{1}^{4}$ & $\begin{array}{r}6.87 \\
1.82\end{array}$ & 8 & $\begin{array}{l}5.63 \\
1.56\end{array}$ & 4 & 3.60 & 4 & $2 \cdot 41$ & 1 & 1.17 & $\begin{array}{ll}36 \\
0\end{array}$ & 0.84 & 0.19 & 0.37 & 2.723 & -1.275 to 15.08 \\
\hline $\begin{array}{l}\text { Thyroud } \\
\text { Ill defined and secondary neoplasms }\end{array}$ & $\begin{array}{r}4 \\
36\end{array}$ & $\begin{array}{r}3.31 \\
43.26\end{array}$ & 11 & $\begin{array}{l}0.68 \\
9.25\end{array}$ & $\frac{1}{10}$ & $\begin{array}{c}1.82 \\
13.56\end{array}$ & 11 & $\begin{array}{l}1.56 \\
9.51\end{array}$ & $\begin{array}{c}0 \\
10\end{array}$ & $\begin{array}{l}0.84 \\
7.32\end{array}$ & $\begin{array}{l}0 \\
8\end{array}$ & $\begin{array}{l}0.51 \\
5.14\end{array}$ & $\begin{array}{l}1 \\
5\end{array}$ & $\begin{array}{l}0.28 \\
2.96\end{array}$ & 91 & $\begin{array}{l}0.50 \\
2.69\end{array}$ & $\begin{array}{l}0.30 \\
0.01\end{array}$ & 0.59 & $\begin{array}{l}1.049 \\
7.823\end{array}$ & $\begin{array}{l}-1.122 \text { to } 12.25 \\
1.825 \text { to. }\end{array}$ \\
\hline Lymphatic or haematopoietic & $\begin{array}{l}36 \\
42\end{array}$ & $\begin{array}{l}43.26 \\
44.08\end{array}$ & 14 & 12.91 & 19 & $\begin{array}{l}13.36 \\
17.77\end{array}$ & 13 & $\begin{array}{l}9.51 \\
12.69\end{array}$ & 6 & $\begin{array}{l}1.32 \\
10.39\end{array}$ & 11 & 7.33 & 4 & 3.84 & $\begin{array}{l}91 \\
109\end{array}$ & 0.55 & 0.30 & 0.61 & 0.607 & -0.865 to 3.432 \\
\hline $\begin{array}{l}\text { Hodgkin's dise } \\
\text { Hod }\end{array}$ & $\begin{array}{r}42 \\
6\end{array}$ & +9.92 & ${ }_{2}^{14}$ & 1.64 & 4 & 2.21 & 1 & ${ }_{1.43}^{12.09}$ & 0 & 1.01 & 0 & 0. & 0 & 0.22 & 13 & -1.38 & ${ }_{75}$ & 0.11 & $<-1.958$ & $<-1.958101 .190$ \\
\hline $\begin{array}{l}\text { Houghkin Sussase } \\
\text { Non-Hodgkin's lymphoma }\end{array}$ & $\begin{array}{c}6 \\
15\end{array}$ & $\begin{array}{r}5.92 \\
14.59\end{array}$ & $\frac{2}{7}$ & $\begin{array}{l}1.64 \\
4.53\end{array}$ & $\frac{4}{7}$ & $\begin{array}{l}2.21 \\
6.24\end{array}$ & 1 & $\begin{array}{l}1.43 \\
4.71\end{array}$ & 3 & $\begin{array}{l}1.01 \\
4.14\end{array}$ & 5 & $\begin{array}{l}0.56 \\
2.63\end{array}$ & $\begin{array}{l}0 \\
0\end{array}$ & $\begin{array}{l}0.22 \\
1.16\end{array}$ & $\begin{array}{l}13 \\
38\end{array}$ & 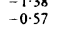 & $\begin{array}{l}0.95 \\
0.69\end{array}$ & 0.61 & $\begin{aligned}<-1.988 \\
-1 \cdot 211\end{aligned}$ & $<-1.958$ to 3.004 \\
\hline myeloma & 5 & 5.41 & 0 & 1.51 & 2 & $2 \cdot 02$ & 3 & 1.26 & 0 & 1.04 & 1 & 1.13 & 2 & 0.63 & 13 & 1.63 & 0.06 & 0.13 & 6.874 & -0.029 to 45.79 \\
\hline \multirow{3}{*}{$\begin{array}{l}\text { Leukaemia (excluding chronic } \\
\text { lymphatic) }\end{array}$} & 24 & $25 \cdot 25$ & 6 & 6.87 & 8 & 9.00 & 6 & 6.27 & 7 & $5 \cdot 38$ & 4 & 3.76 & 4 & $2 \cdot 46$ & 59 & 1.34 & 0.10 & 0.20 & 2.286 & -0.322 to 8.367 \\
\hline & 20 & $21 \cdot 45$ & 4 & 5.34 & 7 & 6.57 & 3 & 4.56 & 5 & 4.13 & 4 & 2.92 & 4 & 2.03 & 47 & 1.95 & 0.03 & 0.07 & $4 \cdot 277$ & 0.3961013 .58 \\
\hline & & & & & & & & & \multirow{2}{*}{\multicolumn{2}{|c|}{$\begin{array}{l}\text { Non-malignant diseuse } \\
201 \quad 196.06\end{array}$}} & & & & & & & & & & \\
\hline Smuking related & 825 & 843.52 & 228 & $210 \cdot 49$ & 326 & $32+95$ & 222 & 244.04 & & & 161 & $136 \cdot 48$ & 63 & $70 \cdot 46$ & 2026 & 0.50 & 0.31 & 0.62 & $0 \cdot 132$ & -0.276 10 0.618 \\
\hline $\begin{array}{l}\text { Circulatory (excluding smoking } \\
\text { related) }\end{array}$ & 274 & 283.05 & 70 & 60.79 & 90 & $93 \cdot 02$ & 81 & $68 \cdot 43$ & 55 & $54: 30$ & 29 & $40 \cdot 19$ & 22 & $21 \cdot 22$ & 621 & -0.69 & 0.75 & 0.49 & -0.279 & -0.799 to 0.466 \\
\hline $\begin{array}{l}\text { Respiatory (excluding smoking } \\
\text { related) }\end{array}$ & 82 & $86.7-7>3$ & 20 & & 27 & 25. & 12 & 17.95 & 14 & 13.76 & 15 & $9 \cdot 93$ & 5 & 5.06 & 175 & 0.90 & 0.18 & 0.37 & 0.946 & -0.582 10 3.569 \\
\hline Digesti & 38 & 35 & 9 & 10.78 & 18 & 17. & 14 & $12 \cdot 61$ & 6 & 9 & 7 & s. & 3 & 3.06 & 95 & -0.18 & & & -0.184 & -1.270 to 2.182 \\
\hline Genitourinary & 17 & $17 \cdot 29$ & 3 & +.07 & 6 & 6.05 & 6 & 4.24 & 5 & 4.06 & 2 & 3.25 & 2 & 2.05 & 41 & -0.19 & & 0.89 & -0.279 & -1.488 to 4.520 \\
\hline Unknown causes & 33 & $28 \cdot 52$ & 13 & 8.34 & 11 & $11 \cdot 80$ & 2 & 7.98 & 5 & 5.96 & 2 & 3.34 & 1 & 1.06 & 67 & -1.43 & 0.93 & 0.13 & $-1 \cdot 241$ & $-1 \cdot 729$ 10 0.281 \\
\hline
\end{tabular}


TABLE VIII-Comparison of risk estimates from studies of Fapanese atomic bomb survivors, National Registry for Radiation Workers, and combined cohort of nuclear workers in United States

\begin{tabular}{|c|c|c|c|c|}
\hline & \multicolumn{2}{|c|}{ Atomic bomb survivors'th } & \multirow{2}{*}{$\begin{array}{l}\text { National } \\
\text { Registry for } \\
\text { Radiation } \\
\text { Workers }\end{array}$} & \multirow{2}{*}{$\begin{array}{l}\text { American } \\
\text { workers }\end{array}$} \\
\hline & Whole cohort & Doses $\leqslant 500 \mathrm{mSv}$ & & \\
\hline Cohort size & 75991 & & 95217 & 35933 \\
\hline Person years & 2185000 & & 1218000 & 705000 \\
\hline Collective dose (man $\mathrm{Sv})$ & 18000 & & 3198 & 1140 \\
\hline Range of doses & $0-4$ or more & $0-0 \cdot 5$ & $0-0.5$ or more & $0-0.5$ or more \\
\hline \multicolumn{5}{|l|}{$\begin{array}{l}\text { Excess relative risk per } \mathrm{Sv} \\
\text { (90\% confidence interval): }\end{array}$} \\
\hline & $\begin{array}{c}0.41 \dagger \\
(0.32 \text { to } 0.52)\end{array}$ & $0 \cdot 38 \ddagger$ & $\begin{array}{c}0 \cdot 47 \\
(-0 \cdot 12 \text { to } 1 \cdot 20)\end{array}$ & $\begin{array}{c}-0.99 \\
(<-1.6 \text { to } 0.38)\end{array}$ \\
\hline Leukaemia & $\begin{array}{c}5 \cdot 2 \ddagger \\
(3 \cdot 8 \text { to } 7 \cdot 1)\end{array}$ & $2 \cdot 4 \ddagger$ & $\begin{array}{c}4 \cdot 3 \\
(0 \cdot 40 \text { to } 13 \cdot 6)\end{array}$ & $\begin{array}{c}<-1.5 \\
(<-1.5 \text { to } 3.4)\end{array}$ \\
\hline \multicolumn{5}{|l|}{$\begin{array}{l}\text { Lifetime risks, \% per } \mathrm{Sv} \\
\quad(90 \% \text { confidence interval): }\end{array}$} \\
\hline All malignant neoplasms & $\begin{array}{c}45 \\
(3 \text { to } 5) \|\end{array}$ & & $\begin{array}{c}10 \\
(<0 \text { to } 26)\end{array}$ & $\begin{array}{c}<0 \\
(<0 \text { to } 8 \cdot 2)\end{array}$ \\
\hline Leukaemia & $\begin{array}{c}0.4 \S \\
(0.3 \text { to } 0.55)\end{array}$ & & $\begin{array}{c}0 \cdot 76 \\
(0 \cdot 07 \text { to } 2 \cdot 4)\end{array}$ & $\begin{array}{c}<0 \\
(<0 \text { to } 0 \cdot 60)\end{array}$ \\
\hline
\end{tabular}

"Workers at Hanford, Oak Ridge and Rocky Flats."

tAll malignant neoplasms excluding leukaemia, based on all ages.

‡All ages at exposure.

SDerived by the International Commission on Radiological Protection applying dose and dose rate effectiveness factor of 2 to data on Japanese survivors.

Approximate values based on Japanese data

estimate from the registry and was similar to that predicted by the Committee on the Biological Effects of Ionising Radiation from the fit of a linear quadratic dose-response model to the Japanese data ${ }^{1720}$; this corresponds to a lifetime risk for a British population of $0.6 \% / \mathrm{Sv}{ }^{21}$ By contrast, the lower limit of the $90 \%$ confidence interval in the analysis of the registry is just above zero in the case of leukaemia and less than zero for all malignant neoplasms. Thus, although the confidence limits for the registry and the American study overlap, the American study points toward lower risks. Thirdly, the risk per unit dose derived from the registry may be subject to some uncertainty because only external dose was considered, and it has not been possible to take into account the possible effects of occupational exposures to other carcinogenic agents (both physical and chemical). However, if the 13500 workers with a collective external recorded dose of about 700 man Sv and known to have been monitored for internal contamination are excluded from the analysis the results are not materially different.

Thus the risk estimates recommended by the International Commission on Radiological Protection, which were derived from high dose and high dose rate exposures, with a dose and dose rate effectiveness factor of 2, occupy a middle position between the risk estimates from two comprehensive studies of workers receiving low doses and low dose rates of radiation. ${ }^{2} 19$ Given the statistical uncertainties, the results from these studies do not indicate that the commission's risk estimates are materially wrong. Nevertheless, the results from the first analysis of the National Registry for Radiation Workers provide valuable evidence, and future analysis of the registry, which will incorporate all registered cohorts and updated dose histories (including internal doses) and have a longer follow up, will provide a firmer basis for deriving risk estimates from low dose and low dose rate exposures.

From its inception the registry has been guided by an advisory committee of eminent epidemiologists. We are grateful to them for their guidance over many years, to Sir Richard Doll for advice, and to Dr Ethel Gilbert for making available some unpublished data.

The registry has relied on cooperation from many individuals and organisations, both within the nuclear industry and outside. We cannot thank here all those who have helped the study, but more detailed acknowledgements can be found elsewhere. ${ }^{2}$

1 Goodwin P. Registry for UK radiation workers. Nature 1975;255:517.

Kendall GM, Muirhead CR, MacGibbon BH, O'Hagan JA, Conquest AJ Goodill AA, et al. Mortality and occupational exposure to radiation: first analysis of the National Registry for Radiation Workers. London: HMSO, 1992 (NRPB-R251.)

3 Darby SC, ed. Protocol for the National Registry for Radiation Workers. London: HMSO, 1981. (NRPB-R116.)

4 Beral V, Inskip H, Fraser P, Booth M, Coleman D, Rose G. Mortality of employees of the United Kingdom Atomic Energy Authority, 1946-1979. BMF 1985;291:440-7.

5 Smith PG, Douglas AJ. Mortality of workers at the Sellafield plant of British Nuclear Fuels. BMf 1986;293:845-54.

6 Beral V, Fraser P, Carpenter L, Booth M, Brown A, Rose G. Mortality of employees of the Atomic Weapons Establishment, 1951-82. BMJ 1988;297: employers

7 Binks K, Thomas DI, McElvenny D. Mortality of workers at the Chapelcross plant of British Nuclear Fuels. In: Goldfinch EP, ed. Radiation protection plant of British Nuclear Fuels. In: Goldfinch EP, ed. Radia

8 Coleman M, Douglas A, Hermon C, Peto J. Cohort analysis with a FORTRAN computer program. Int $\mathcal{F}$ Epidemiol 1986;15:134-7.

9 Fox AJ, Collier PF. Low mortality rates in industrial cohort studies due to selection for work and survival in the industry. $\mathrm{Br} \mathcal{F}$ Prev Soc Med 1976;30:225-30.

10 Registrar General. Decennial supplement, England and Wales, 1961, occupational mortality. Tables. London: HMSO, 1971.

11 Office of Population Censuses and Surveys. Occupational mortality 1970-72. London: HMSO, 1978. (DS No 1.)

12 Office of Population Censuses and Surveys. Occupational mortality 1979-80, 1982-3. London: HMSO, 1986. (DS No 6.)

13 Darby SC, Reissland JA. Low levels of ionising radiation and cancer-are we underestimating the risk? Fournal of the Royal Statistical Society A 1981;144 underestim

14 Barry SF. ARFAR: a person years at risk program. Br $\mathcal{F}$ Ind Med 1986;43:

15 Cox DR, Hinkley DV. Theoretical statistics. London: Chapman and Hall, 1974 16 Shimizu Y, Kato H, Schull WJ. Studies of the mortality of A-bomb survivors. 9. Mortality, 1950-1985: part 2. Cancer mortality based on the recently revised doses (DS 86). Radiat Res 1990;121:120-41.

17 Committee on the Biological Effects of Ionising Radiation (BEIR V). Health effects of exposure to low levels of ionising radiation. Washington, DC: National Academy Press, 1990.

18 International Commission on Radiological Protection. 1990 recommendations of the International Commission on Radiological Protection. Ann ICRP 1991;21:1-3. (ICRP Publication 60.)

19 Gilbert ES, Fry SA, Wiggs LD, Voelz GL, Cragle DL, Petersen GR. Analyses of combined mortality data on workers at the Hanford site, Oak Ridge National Laboratory and Rocky Flats nuclear weapons plant. Radiat Res 1989:120:19-35.

20 Gilbert ES. Statistical methods for analysing and combining data on low level exposures to ionising radiation. Radiat Res 1990;124:348-9.

21 Muirhead CR. Projection of radiation-induced cancer risks across time and populations. Radiation Protection Dosimetry. 1991;36:321-5.

(Accepted 19 December 1991)
Correspondence to:

Dr I C Macdougall,

Department of Nephrology,

St Bartholomew's Hospital,

London EC1A 7BE.

BMF 1992;304:225-6

\section{Detection of functional iron deficiency during erythropoietin treatment: a new approach}

Iain C Macdougall, Ivor Cavill, Barry Hulme,
Barbara Bain, Ellon McGregor, Pamela McKay,
Eric Sanders, Gerald A Coles, John D Williams

Erythropoietin treatment may cause functional iron deficiency in patients receiving long term dialysis. ${ }^{1.3}$ Such deficiency is currently detected by low transferrin saturation,,$^{1.3}$ which has considerable limitations because saturation varies substantially even in normal, healthy subjects. ${ }^{45}$
We conducted a multicentre prospective study of a new and more direct method of detecting iron deficient erythropoiesis. This entailed serial measurement of the percentage of hypochromic and microcytic red cells in the circulation with an automated blood count analyser.

\section{Patients, methods, and results}

Forty six patients were studied (17 from Cardiff Royal Infirmary; 15 from St Mary's Hospital, London; five from the Western Infirmary, Glasgow; and nine from West Wales General Hospital, Carmarthen). Twenty two were male and 24 female; 30 were receiving regular haemodialysis and 16 continuous ambulatory peritoneal dialysis. Nineteen patients were treated with intravenous erythropoietin 1200-4000 units thrice weekly and 27 with subcutaneous erythro- 